\title{
EXCLUSION OF JAPANESE CHILDREN FROM THE PUBLIC SCHOOLS OF SAN FRANCISCO.
}

The recent action of the Board of Education of San Francisco in excluding Japanese children from the public schools for white children and requiring that if they attend public school at all it shall be the Oriental schools, has given rise to friction between the two countries. The Japanese consul in San Francisco protested against this action and the protest was brought to the attention of the government at Washington by Count Aoki, the Japanese ambassador. In order to determine whether or not. the Japanese are warranted in protesting, it is necessary to examine the ground upon which their protest rests. They insist that the action deprives them of a right guaranteed in the treaty between the United States and Japan signed at Washington in November, 1894 , and ratified in February, 1895. Article $I$ of this treaty reads as follows:

The citizens or subjects of each of the two high contracting parties shall have fuil liberty to enter, travel, or reside in any part of the territories of the other contracting party, and shall enjoy full and perfect protection for their persons and property. * * * In whatever relates to rights of residence and travel; to the possession of goods and effects of any kind; to the succession to personal estate by will or otherwise, and the disposal of property of any sort and in any manner whatsoever which they may lawfully acquire the citizens or subjects of each contracting party shall enjoy in the territories of the other the same privileges, liberties and rights, and shall be subject to no higher imposts or charges in these respects than native citizens or subjects, or citizens or subjects of the most favored nation.

In view of the provisions of this treaty, it is clear that the Japanese have a grievance. The subjects of Japan are discriminated against; for, although treated upon an equality with Chinese and Coreans they are denied privileges accorded to subjects of Great Britain, Germany, France, Italy, Russia, Austria, etc. Whether the privileges accorded them of attending the Oriental schools is a sufficient compensation for depriving them of the right to attend the American public schools, so that the grievance is a purely technical and not a substantial one, is a matter of which the United States is not the sole judge. We must concede to the Japanese equal rights with ourselves in judging of this matter. It is entirely clear that if 
they wish their children to become Americans, the privilege of sending them to the public schools is one of inestimable value. It cannot have escaped the observant and quick-witted Japanese that our public school is the greatest institution on earth for making Americans; that but for it the millions of immigrants who have come to this country could never have been assimilated, but would have remained a foreign substance in the body politic and would gradually have changed the American people from a distinctive unified type to a most conglomerate mass of individuals.

To this it has been objected that the Japanese do not want to become and will not become Americans. Yet here again it will not do for us to constitute ourselves as judge and jury. We must concede to the Japanese some right to a hearing when determining the question of their intentions. As regards a matter of that sort their opinion should be allowed to count for something.

Except in those sections of the country whose race prejudice has dimmed the vision and dissipated the sense of fairness, it is admitted that during the life of the treaty of 1894 between the United States and Japan the latter is entitled to insist that its subjects shall not be discriminated against and that it is the duty of the United States to see that they are not. This in substance is admitted by the federal government. But here comes in an awkward provision in our system of government, a provision which, as usually interpreted, is not only awkward but ridiculous. I refer to the traditional conception of the distribution of powers between the state and federal governments. According to this the sphere within which a state is supposed to have exclusive jurisdiction is something so sacred that the mere fact that the federal government must assume responsibility for what is done, or for a failure to act, must not be thought of as giving it a right to interfere in order to protect its interests and its honor.

The present case is not the first in which adherence to the above theory has threatened international complications. It will be recalled that in $185 \mathrm{I}$ a mob destroyed the building containing the Spanish consulate in New Orleans and looted several cigar stores owned by Spaniards. The United States acknowledged its responsibility for the damage done, apologized to the Spanish government and provided that the ship on which its consul should return should be saluted as a mark of respect. But it did not claim jurisdiction to punish the wrongdoers and thus discourage a similar outbreak in the future.

This act of the mob, although directed in part against the official 
of a foreign government did not cause nearly so much friction as when in $189 \mathrm{I}$ a mob broke into the jail in New Orleans and put to death three Italian subjects. Italy at once demanded assurance from the United States that the offenders would be punished and that an indemnity would be paid to the relatives of the victims. The United States replied by assuring the Italian government that it would "recompense every Italian subject who might be wronged by the violation of a treaty to which the faith of the United States is pledged," and that it would urge the state of Louisiana to see that justice was meted out to the offenders but claimed that it had no authority to institute proceedings against them itself and that hence it could not give to Italy assurance that proceedings would be instituted. Though Italy exhibited a lack of patience and selfcontrol in withdrawing her minister as hastily as she did, there is considerable excuse for the complaint of that government uttered by her minister for foreign affairs, Rudini, that "We are under the sad necessity of concluding that what to every other government would be the accomplishment of simple duty is impossible to the federal government. We have affirmed, and we again affirm our right. Let the federal government reflect upon its side if it is expedient to leave to the mercy of each state of the Union, irresponsible to foreign countries, the efficiency of treaties pledging its faith and honor to entire nations." Such was the state of public opinion in New Orleans that the offenders were not brought to trial and though we escaped by the payment of an indemnity, the awkward and embarrassing position in which we were placed should have led us to seek a guarantee against a recurrence of the necessity for pleading a non-possumus when called upon to fulfil our treaty obligations.

. In his message to Congress of December 9, I89r, President Harrison called the attention of Congress to the unfortunate affair in the following language: "Some suggestions growing out of the unhappy incident are worthy the attention of Congress. It would, I believe, be entirely competent for Congress to make offenses against the treaty rights of foreigners domiciled in the United States cognizable in the federal courts. This has not, however, been done, and the federal officers and courts have no power to intervene, either for the protection of a foreign citizen or for the punishment of his slayers. It seems to me to follow, in this state of the law, that the officers of the state charged with police and judicial powers in such cases must in the consideration of international questions growing out of such incidents be regarded in such sense 
as federal agents as to make this government answerable for their acts in cases where it would be answerable if the United States had used its constitutional power to define and punish crime against treaty rights."

The present case does not involve a question of criminal jurisdiction, and so is not in all respects parallel to the New Orleans affair, but it does involve a matter in which the United States has by treaty made itself responsible for acts ordinarily regulated exclusively by the state. Though the Japanese are showing greater patience than did Italy, there is every reason to believe that they will show greater firmness. The Board of Education claims that its action is in accordance with the statutes of California and that it will not rescind its action unless compelled by the courts to do so. A test case is being brought for the purpose of testing the constitutionality of the statute. Section 2, Article VI, of the Constitution of the United States provides that "This Constitution and the laws of the United States which shall be made in pursuance thereof; and all treaties made, or which shall be made, under the authority of the United States, shall be the supreme law of the land, anything in the constitution or laws of any state to the contrary notwithstanding." As the statute conflicts with the treaty of 1894 , which was "made under the authority of the United States," it is unconstitutional and cannot give the Board of Education authority to take the action which it has taken under it. If, then, the state court does its duty, a solution for the difficulty can readily be found.

But suppose that the state court allows itself to be blinded by the race prejudice which influenced the legislature to pass the statute, the litigation can be prolonged to such a degree that the Japanese may readily conclude that we are not acting in good faith, for it is hardly fair to expect that the Japanese people will understand that our federal government which is entrusted with the making of treaties cannot also secure obedience to their provisions upon the part of its subordinate divisions.

Whether or not the present case is one which can be brought directly into the federal courts, with legislation by Congress providing therefor, is a question of jurisdiction which is as interesting as it is difficult, and will be reserved for discussion in a subsequent article. Edriin :IIarcy', LL.D. 